\title{
Analysis Of Predisposing, Enabling And Reinforcing Factors With The Implementation Of The Role Of Cadad In Prevention Stunting In The Lombok Central Region Region West Nusa Tenggara
}

\author{
Asmawati \\ Magister of Health Study Program \\ of Institut Ilmu Kesehatan \\ STRADA Indonesia \\ Email: \\ asmawati@gmail.com
}

Received : October 12, 2019

Accepted : February 13, 2020

Published : May 12, 2020

\begin{abstract}
The occurrence of anemia in adolescents due to lack of nutrients transport and oxygen throughout body to be inhibited, in the brain this causes a decrease in the level of concentration. This decrease in concentration level is more severe if anemic sufferers have low emotional intelligence because it is increasingly difficult for adolescents to carry out a concentration of mind. The purpose of this study is to influence the incidence of anemia and emotional quotient on the level of student learning concentration of Pule 1 Senior High School Trenggalek Regency. The design of this research is correlational analytic with cross sectional approach. Data collected by questionnaire an dobservastion sheet, data analysis by ordinal regression test at $\alpha=0.05$. The results showed that there was an influence of anemia against concentration level in SMAN 1 Pule in Trenggalek Regency ( $\mathrm{p}$-value $=0,000$ ), there was an emotional quotient effect against concentration level in SMAN 1 Pule in Trenggalek Regency $(\mathrm{p}$-value $=0.011)$ and together there is an influence of the incidence of anemia and emotional quotient against concentration level in Pule 1 Senior High School, Trenggalek Regency ( $\mathrm{p}$-value $=0,000)$. Adolescents who experienced anemia will experience a decrease in the body's metabolism because one component of metabolism that is oxygen cannot be supplied smoothly so that the body's energy decreases, especially in the brain will have an impact on decreased concentration in the learning process. Relation to emotional intelligence, through good emotional intelligence, a student can manage his time well so that he is able to place the utilization of the time he has for his main task of learning. Through emotion management, EQ plays a role in supporting self-control and time management so that students who have high EQ will not be easily affected by environmental disturbances so that they can carry out the learning process with good concentration.
\end{abstract}

Keywords: Learning Concentration, Anemia, Emotional Quotient, Adolescents 


\section{INTRODUCTION}

Efforts to realize quality human beings must be done early, especially at school age, because at this age cognitive, motor and emotional development develops rapidly. Cognitive development that is closely related to abilities in learning, memory, reasoning, thinking, and language is very influential on school learning achievement (Jahja, 2013). Changes in lifestyle and eating habits as an environmental influence have changed into a lifestyle that is almost instant and often begins in adolescence (Citrakesumasari, 2012). Adolescence is an age where all physical and cognitive development approaches its peak, all these changes require an increase in the intake of nutrients specifically. Therefore, adolescence becomes a vulnerable period of nutrition due to an imbalance between intake and nutritional needs due to changes that occur (Almatsier et al. 2011).

One of the health problems related to nutrition that often occurs in adolescents is anemia. Adolescents who suffer from anemia will experience stunted growth processes, motor skills, mental and intelligence as well as decreased levels of fitness, memory, immune power and concentration power so that it has an impact on low learning abilities and affects learning achievement (Adriani, 2014). Concentration is one of the main factors that influence learning. The higher the concentration the more effective the learning activity. According to Sediaoetama (2014) the occurrence of iron deficiency anemia affects the amount of hemoglobin in the blood that functions to carry oxygen throughout the body, lack of oxygen in the brain tissue will make the brain run slow so that it triggers drowsiness and decreased concentration.

WHO data (2012) shows that approximately $24.8 \%$ or 1.62 billion of the world's population suffer from anemia and 25.4\% of them are teenagers. In Southeast Asia too, 13.6\% of adolescents suffer from anemia. Figures in Indonesia are also high. This can be demonstrated through research by the Indonesian Pediatrician Association (IDAI) on 1,000 school children in 11 provinces in Indonesia showing an anemia prevalence of 20-25\% (Sitanggang, 2012). Based on WHO research in 2010-2015, around $48.8 \%$ of the world's population is affected by anemia. The prevalence in men who experience anemia symptoms worldwide is $40.2 \%$. The prevalence of population in Asia found men who experience anemia symptoms by $47.6 \%$. Obtained also in Southeast Asia, the number of residents, especially men who experience anemia symptoms as much as $4.1 \%$. Based on the RISKESDAS survey in 20138 , the prevalence of anemia in men in Indonesia was $16.6 \%$.

Anemia incidence rate is based on the results of the selection carried out by the Trenggalek District Health Office in all high schools and the equivalent in Kab. Trenggalek showed 222 students (33.08\%) of the 671 students examined had anemia (Denges District of Trengalek, 2017). The results of screening conducted by the Trenggalek District Health Office in SMAN 1 Pule Trenggalek in 2018 of class X students showed that out of 172 students, 61 students $(35.5 \%)$ had mild anemia status consisting of 23 male students (38\%) and 38 students (62\%) women (Trenggalek District Health Office, 2019).

Anemia that is often found is due to iron deficiency or deficiency, namely the state of hemoglobin levels and the count of erythrocytes and hematocrit which is below the normal limit due to lack of nutrition, especially iron (Arisman, 2014). Decreased hemoglohin levels in adolescents are also caused by blood loss due to menstruation, lack of iron in food consumed, chronic diseases, such as tuberculosis, hepatitis, etc. lack of sleep, an imbalance between nutritional intake and activities undertaken (Permaesih, 2015). In children who lack iron cause apathy, irritability, decreased ability to concentrate and learn (Almatsier, 2012).

The effect of iron deficiency is mainly through the condition of impaired function of hemoglobin which is an $\mathrm{O} 2$ transport tool, which is required by many metabolic reactions in the body. It is said that in anemic conditions the power of concentration in learning will decrease (Gibney, 2009). Pinero's results (2011) prove that iron deficiency can cause a decrease in motor sensory development due to reduced levels of dopamine receptors in the brain, decreased production of myelin (hypomyelination) and impaired metabolism of monoamine neurotransmitters, thereby affecting the decrease in brain work. Rachmawati (2013) added that iron as an oxygen-carrying pigment (O2) in the blood is needed by the body for the combustion process that produces energy. Lack of $\mathrm{O} 2$ levels in the blood causes disruption of cell functions throughout the body including the brain.

Learning concentration is the ability to focus and maintain the mind in the form of attention to something that is being learned. Concentration plays an important role for school children to remember, record, continue, and develop learning material obtained at school (Aviana, 2015). Besides being 
anemic, the concentration of learning can also be caused by a weak ability to concentrate, this is caused by a split mind (duplication of thoughts). Branched thoughts can arise unnoticed. When learning, sometimes surfaces of the mind about old problems, other desires so that they interfere with learning activities. Finally someone can switch and dissolve into the mind that passes (Mudjiono, 2013).

A mind control strategy to achieve a good level of learning concentration requires good emotional intelligence. Emotional quotient (EQ) is the ability to motivate yourself, overcome frustration and control the urge of the heart (Goleman, 2012). In the learning process, students who have high emotional intelligence will be better able to overcome the problems that occur around them and be able to do mind management to prioritize what they have to do first.

In accordance with the statement of Tjundjing (2011), said that a low level of emotional intelligence will result in a person unable to use his cognitive abilities with maximum potential and usually tends to be more easily discouraged. This is due to many factors that influence emotional intelligence including age, genetics, environment, parenting etc. Whereas for high emotional intelligence will affect cognitive skills contained in aspects of academic achievement, because cognitive skills can explain the ability of students to manage their learning systems.

Efforts that can be made to overcome the low concentration of student learning are by overcoming two factors that are often possessed by adolescents, namely by preventing anemia and by increasing adolescent emotional intelligence considering adolescents have various problems that can interfere with their minds. Prevention of anemia can be done by increasing the intake of nutrients in adolescents, especially consumption of protein sources that contain high iron such as meat, and consuming natural iron sources such as green vegetables (Simanjuntak, 2010). Efforts to screen in schools by giving Fe tablets have been considered effective to reduce the incidence of anemia in adolescents (Proverawati, 2010). Increased consumption of protein and iron that can be obtained from the consumption of red meat will encourage the increase in $\mathrm{Hb}$ production thereby reducing the risk of anemia (Almaitzer, 2012).

Associated with emotional intelligence, efforts are needed to always think positively to everything, regulate the learning process and adapt to the new learning environment, remembering that a student always meets with new classmates so that a good level of adaptation is needed so that students can obtain a high concentration of learning so that it can improve learning achievement (Wahyuningsih, 2014).

\section{METHODS}

The design of this research is correlational analytic with cross sectional approach. The population studied was all students of class XI of SMAN 1 Pule, Trenggalek Regency using simple random sampling technique (124 respondents). The independent variables are anemia status (X1) and emotional quotient (X2). The dependent variable is anemia status. Data collection using a questionnaire, data analysis with logistic regression tests at $\alpha=0.05$.

\section{RESULT}

Analisys

The results of tests using multiple ordinal regression to the effect of anemia status and emotional quotient on the level of concentration in students of SMAN 1 Pule Trenggalek Regency obtained the following results:

Tabel 1 Results Analysis of the effect of anemia status and emotional quotient on the level of concentration in students of SMAN 1 Pule, Trenggalek Regency

\begin{tabular}{|l|c|c|c|c|}
\hline \multirow{2}{*}{ Variabel } & \multirow{2}{*}{ Estimate } & \multirow{2}{*}{ Sig. } & \multicolumn{2}{c|}{ 95\% Confidence Interval } \\
\cline { 4 - 5 } & & & Lower Bound & Upper Bound \\
\hline Anemia & -3.117 & 0,000 & -4.171 & -2.063 \\
\hline Emotional Quotient & 0,698 & 0,011 & 0,160 & 1,236 \\
\hline Simultan & - & 0,000 & - & - \\
\hline
\end{tabular}

The analysis results obtained p-value $=0,000<\alpha=0.05$ so that $\mathrm{H} 0$ is rejected and $\mathrm{H} 1$ is accepted, which means that anemia status significantly influences the level of concentration in students of SMAN 1 Pule, Trenggalek Regency. The analysis results obtained p-value $=0.011<\alpha=0.05$ so that $\mathrm{H} 0$ is 
rejected and $\mathrm{H} 1$ is accepted, which means emotional quotient has a significant effect on the level of concentration in students of SMAN 1 Pule, Trenggalek Regency. The results of the ordinal regression analysis together are known $\mathrm{p}$-value $=0,000<\alpha(0.05)$ so that $\mathrm{H} 0$ is rejected and $\mathrm{H} 1$ is accepted which means that together there is an influence of anemia status and emotional quotient on the concentration level in SMAN 1 Pule students in Trenggalek Regency. Based on the value of the odd ratio it can be interpreted that:

1. Anemia status has a negative effect on the level of concentration, in the sense that by having anemic status, students tend to have a concentration level of 2.117 times lower when compared to students who do not have anemia.

2. Emotional quotinet has a negative positive effect on the level of concentration, in the sense that by having a high emotional quotient, students tend to have a concentration level of 0.698 times higher when compared to students who have a low emotional quotient.

3. Based on the value of odd ratio or estimate it can be concluded that the anemia status factor is the most influential factor on the concentration level of students with an odd ratio value of -2.117 at the lower limit of -4.171 and the upper limit of -2.063 .

\section{DISCUSSION}

\section{Anemia status in students of SMAN 1 Pule, Trenggalek Regency}

Anemia status in students of SMAN 1 Pule in Trenggalek Regency is known that the majority of respondents had anemic events in the category of no anemia, namely 77 respondents $(62 \%)$.

Rapid growth in adolescents gives the consequence of an increase in nutritional needs in an effort to offset this growth. But the data shows that the food intake of young women cannot provide enough nutrients to meet their needs due to lack of iron intake (Krumel, 2016). The consumption patterns of adolescents who are lacking in quality and tend to consume only high carbohydrate foods have an impact on the occurrence of micronutrient intake deficiency as well as iron, thus inhibiting the formation of hemoglobin which causes anemia. In addition, low protein consumption also causes anemia because the formation of hemoglobin also requires protein to form heme chains (Simanjuntak, 2010)

The results showed that the majority of respondents had anemia. This condition can be caused by various factors. The prevalence of anemia is quite large in adolescents because in adolescence there is rapid growth (growth spurt). During the teenage period, bone mass increases and bone remodeling occurs; soft tissue, organs, and even red blood cell mass increases in size. This growth caused iron demand to increase dramatically and it was at this adolescent that nutritional requirements reached their highest point. If the nutritional intake of adolescents is lacking, anemia can easily develop. In terms of the results of the cross tabulation, it is known that respondents who do not always have breakfast when leaving for school tend to experience anemia. For teenagers who are still in school, breakfast is a source of energy for activities and learning activities at school. Breakfast is the most important activity in meeting energy and nutrient needs in a day. Skipping breakfast can have an impact on reducing nutritional intake including iron in the blood which can cause anemia.

In adolescence generally begins to decrease vegetable consumption and prefers the consumption of instant foods so that the risk of causing anemia even though on a mild level. This condition shows that consumption of Fe-containing vegetables such as spinach and kale is important to prevent respondents from being exposed to anemia, although both are sources of iron, but vegetables can provide higher benefits in an effort to increase hemoglobin levels compared to meat consumption.

\section{Emotional quotient in students of SMAN 1 Pule, Trenggalek Regency}

Emotional intelligence or EQ is not based on a child's intelligence, but on what used to be called personal characteristics. Research now finds that these social and emotional skills may be even more important for life success than intellectual abilities. In other words, having a high EQ might be more important in achieving success than a high IQ measured by standardized tests of verbal and nonverbal cognitive intelligence (Belly, 2016). Salovey \& Jack Mayer, (2014) add that EQ is a set of skills that allows us to pave the way in a complicated world - personal, social, and defense aspects of all intelligence. The results of Hans and Johnson's research (2012) show that emotional intelligence helps students in building a surrounding social community so that it influences student motivation, and influences students' ability to understand stimuli provided in the learning process. 
The results showed that the majority of respondents had a medium EQ category. This shows that the respondent is still unable to control his emotions so that not every time the respondent is able to suppress external confounding factors that can affect his concentration as a student who has quite a lot of assignments.

During this time many people assume that if someone has a high level of intellectual intelligence or so-called Intellegence Quotient (IQ), then that person has the opportunity to achieve greater success compared to others. In fact, there are many cases where someone who has a high level of intellectual intelligence is excluded from someone who has a lower level of intellectual intelligence. It turns out that a high IQ does not guarantee someone will achieve success. Emotional intelligence (EQ) is not the opposite of IQ or cognitive intelligence, but both interact dynamically both conceptually and in the real world.

IQ is based on neocortex work, which is a layer that in evolution developed most recently in the upper part of the brain. The emotional centers are in the deeper parts of the brain that evolved first. Brain function in this section affects EQ. However the activities of these emotional centers remain in harmony with the work activities of the intellectual centers. EQ is very important in the success of life. For example, when someone upset other people with abusive behavior, do not know how to carry and position themselves or despair just because of a little stress, then other people will not feel comfortable with him no matter how high his IQ. In relation to the concentration of learning, students who have high EQ will be able to master their emotions to be more confident, optimistic, have enthusiasm and ideals, have the ability to adapt so that they will be better able to understand and master the problems around them. His emotional intelligence plays a role in controlling his emotions and thoughts and being able to put himself in the most advantageous position for himself, this will affect the level of concentration of students being high because they are able to filter out negative influences in the environment.

\section{The level of concentration in students of SMAN 1 Pule, Trenggalek Regency}

The level of concentration in students of SMAN 1 Pule in Trenggalek Regency is known that the majority of respondents have a level of concentration in the medium category, namely 61 respondents $(49 \%)$.

Concentration is an attempt to focus attention on an object being studied so that one can understand what is being considered (Julianto, 2014). Concentration is very much needed in various activities, where it is related to one's efforts to pay attention to something that is being done (Apriyani, 2015). Every time you want to do something well and right, then someone needs to focus their thoughts and attention on what they want to do (Thohir, Nugraheni and jannah, 2014). Similarly in terms of learning, a good concentration will help someone to absorb the material being studied so that the expected learning objectives can be achieved (Hermawan, 2014).

The results showed that the concentration of student learning was in the moderate category. This shows that the concentration of students is less than the maximum and can be distracted by disturbances in the surrounding environment. In relation to learning activities, the moderate level of concentration can make it difficult for students to focus on learning so as to reduce the level of absorption and understanding of information given by the instructor. The higher the concentration, the more effective the learning activity, but conversely if the concentration is low, the results obtained are not optimal. Learning difficulties due to lack of concentration causes the value or learning outcomes obtained by students to be not optimal.

\section{Effect of Anemia Occurrence on the level of concentration in students of SMAN 1 Pule, Trenggalek Regency}

Based on the cross tabulation it is known that respondents with no anemia have a moderate level of concentration, which is 39 respondents $(31.5 \%)$. The results of ordinal regression analysis of the incidence of anemia variables (X1) showed p-value $=0,000<\alpha=0.05$ so that $\mathrm{H} 0$ was rejected and $\mathrm{H} 1$ was accepted, which means there was an influence of the incidence of anemia on the level of concentration in students of SMAN 1 Pule in Trenggalek Regency.

Adolescents who experience anemia will experience a decrease in body metabolism because one component of metabolism that is oxygen cannot be supplied smoothly so that the body's energy decreases which results in decreased concentration in the learning process this condition only applies to students who have suffered from severe anemia (Almatzier, 2014). Anemia does not occur suddenly, 
but through several stages. Initially, iron stores in the body decrease, thus reducing the production of hemoglobin and red blood cells slowly (Ganong, 2012). Sritippayawan (2012), states that changes in adolescent consumption patterns that are dominated by food that is not quality and poor in iron causes a lack of daily iron intake. In addition to lack of intake of iron, protein, folic acid, vitamin B12 from daily food also allows anemia, given the importance of these elements in the formation of red blood cells.

Anemia is a condition that shows a person's hemoglobin $(\mathrm{Hb})$ level is lower than normal hemoglobin levels. This is caused by a lack of iron which is needed for the formation of hemoglobin in the body. Anemia causes the capacity to transport oxygen by red blood cells to decrease. In cases of anemia, adolescents with anemia are generally indicated by the condition of the body will look lethargic, easily tired, dizzy, decreased appetite, lack of concentration. But if it is not immediately overcome, the child will experience hearing loss, vision, more emotional, hyperactive, difficult to receive and process information, forgetful, so that it inhibits the learning process, consequently the learning concentration decreases dramatically.

Children suffering from anemia are described as apathetic, irritable, and have little regard for surroundings. Lack of iron has an association with aldehyde-oxidase enzymes in the brain which results in decreased ability to pay attention to something. Anemia also causes memory and concentration power to be low. This is consistent with research conducted by the Asian Development Bank (ADB) which states that anemic children can cause a loss of intellectual intelligence of 5 to 15 points (Ristrini, 2014).

Iron deficiency anemia in adolescence has been shown to negatively affect concentration levels. It was further discussed that this anemia status would adversely affect grades obtained in school, limited mobility and delay in the maturity of the brain's nerves. This is due to iron is a substance that is needed in the development of the nervous system because iron is needed in the synthesis process in it. In addition, iron is one of the substances that is very important as an electron transmitter system in the mitochondria so that iron deficiency will cause a decrease in cytochromes in the mitochondria that will cause growth disorders, even growth abnormalities including intellectual intelligence in children suffering from deficiency anemia. iron.

The results of this study are supported by the results of Pratama's research (2017) which found that there was a correlation between hemoglobin levels and the concentration of students in FKU HKBP Nommensen Medan ( $\mathrm{p}=0.018)$. According to him hemoglobin is an important molecule in the body that is used as a means of transporting oxygen throughout the body. Without hemoglobin, oxygen in the lungs cannot be transported and will result in less or not fulfilling oxygen levels in every cell of the body and brain. The incomplete supply of oxygen throughout the body results in a lack of fuel to be produced, because oxygen is one of the ingredients in the manufacture of Adenosine Triphosphate (ATP) where ATP is a molecule used to store energy resulting from metabolism to be used in all activities of the organs including the brain . Lack of ATP molecule will cause the whole work of the brain to slow down, giving rise to sleepiness as a form of warning that the body is lacking energy and needs rest

\section{The Influence of Emotional quotient on the Concentration Level on the students of SMAN 1 Pule, Trenggalek Regency}

Based on the cross tabulation it is known that respondents with moderate emotional quotient have a level of concentration in the medium category, namely 32 respondents $(25.8 \%)$. The results of the ordinal regression analysis of emotional quotient variables (X2) showed $\mathrm{p}$-value $=0.011<\alpha=0.05$ so that $\mathrm{H} 0$ was rejected and $\mathrm{H} 1$ was accepted, which means there was an emotional quotient effect on the level of concentration in SMAN 1 Pule students in Trenggalek Regency.

Emotional intelligence is a form of one's ability to feel, understand, and effectively apply emotional power and sensitivity as a source of energy, information, connections, and humane influence Goleman (2015). Emotional intelligence is a success factor that determines achievement in organizations, including decision making, leadership, technical breakthroughs and strategies, open and honest communication, teamwork or team work and relationships of mutual trust, customer loyalty, and creativity and innovation (Thamin, 2009). A low level of emotional intelligence will result in a person being unable to use his cognitive abilities with maximum potential and is usually more likely to despair. This is due to many factors that influence emotional intelligence including age, genetics, environment, parenting etc. Whereas for high emotional intelligence will affect cognitive skills contained in aspects 
of academic achievement, because cognitive skills can explain the ability of students to manage their learning systems (Tjundjing, 2011).

Learning achievement is also influenced by factors from within, including difficulties in the use of learning time and emotional intelligence factors of students which is the ability to recognize our own feelings and the feelings of others, the ability to motivate yourself, and the ability to manage emotions well on yourself and relationships with other people. Goleman (2000: 45) defines emotional intelligence as the ability to motivate oneself and survive in the face of frustration; controlling impulse and not exaggerating pleasure, being able to regulate moods and keeping stress burden crippling the ability to think, empathize and pray. Emotional intelligence enriches the ability to associative thinking which helps create associations between things, this way of thinking uses the heart and body. Structures in the brain are used for associative thinking that it can interact with experience and can continue to develop through experience or experimentation.

Through good emotional intelligence, a student can manage his time well so as to be able to place the utilization of the time he has for his main task, namely learning. Through good emotional management, students are not easily influenced by their peers so they can carry out the learning process effectively. Students are accustomed to trying to train and familiarize themselves to be consistent in utilizing their study time, namely having the right learning plan in accordance with the scheduled time, and studying the best times for him to learn, so that he has a disciplined attitude of time. In utilizing time for learning, it is important to pay attention to the accuracy and regularity of each student, because in the use of learning time it is very important in order to obtain truly satisfying learning outcomes.

\section{The Influence of Anemia and Emotional Quotient Status on the Concentration Level in the students of SMAN 1 Pule, Trenggalek Regency}

Analysis together using the ordinal regression test showed $\mathrm{p}$-value $=0,000<\alpha=0.05$ so that $\mathrm{H} 0$ was rejected and $\mathrm{H} 1$ was accepted, which means there was an influence of anemia status and emotional quotient on the level of concentration in the students of SMAN 1 Pule, Trenggalek Regency.

Children suffering from anemia are described as apathetic, irritable and have little regard for their surroundings. Lack of iron has an association with aldehyde-oxidase enzymes in the brain which results in decreased ability to pay attention to something. Anemia also causes memory and concentration power to be low (Ristrini, 2017). A person's cognitive intelligence is closely related to one's anemia status (Hardinsyah 2015). Children who have good anemia status and have good habits, will have good intelligence too. Anemia status will affect one's intelligence level and one's ability to capture lessons, so someone who has normal anemia status will have a better grasp and can get good achievements. Conversely, if someone has anemia will have an impact on intelligence so that it is less optimal in capturing information and focusing attention.

According to the results of Luo's research (2010), anemia status causes students difficulty in understanding a learning material because the process of brain nerve smoothing runs slowly due to weakening metabolism and energy production that can support it. A person's ability to control their emotions properly will affect the process of thinking positively as well. Someone with a 'good emotional intelligence' tend to be more able to control anger and even direct their energy in a more positive direction, not toward negative or destructive expressions (Satiadarma, 2013).

Someone who is suffering from iron deficiency anemia, then the amount of hemoglobin in his blood is lower compared to people who are not anemic. Hemoglobin is the main protein in the human body that functions to transport oxygen from the lungs to the peripheral tissues and transport carbon dioxide from the peripheral tissues to the lungs. Someone who has a Hb level in the blood lower than normal, causes disruption in the learning process, either due to decreased memory or reduced ability to concentrate. To be able to maintain memory and the ability to concentrate requires the available energy in the body. The energy is obtained from food that enters the body through a series of metabolic processes.

In addition to the problem of anemia, one of the factors that in this study also affects student achievement is emotional intelligence. This condition shows that emotional intelligence can improve the ability of respondents to regulate the learning process and adapt to a new environment, considering that a nursing student is required to always practice in a variety of different places, this adaptation ability is important to obtain maximum learning achievement. People with well-developed emotional skills mean that they are more likely to be happy and successful in life, mastering the habits of the mind that 
drive their productivity. People who cannot gain certain control over their emotional life will experience inner battles that rob them of their ability to concentrate on tasks or work or to have a clear mind.

\section{CONCLUSION}

1. Most respondents have anemia status in the category does not occur, namely 77 respondents $(62 \%)$.

2. Most respondents have emotional quotient in the medium category, which is 64 respondents $(52 \%)$

3. Most respondents have a level of concentration in the medium category, namely 61 respondents $(49 \%)$.

4. There is an influence of anemia status on the level of concentration in students of SMAN 1 Pule, Trenggalek Regency (p-value $=0,000$ ).

5. There is an emotional quotient effect on the level of concentration in students of SMAN 1 Pule in Trenggalek Regency (p-value $=0.011$ ).

6. There is an influence of anemia status and emotional quotient on the level of concentration in students of SMAN 1 Pule, Trenggalek Regency $(\mathrm{p}$-value $=0,000)$

\section{REFERENCES}

Almatsier, S. 2012. Prinsip Dasar Ilmu Gizi. Jakarta: PT Gramedia Pustaka Utama

Arisman. 2014. Gizi Dalam Daur Kehidupan. Jakarta : EGC

Aunurrahman, 2016. Psikologi Belajar, Jakarta : PT Rineka Cipta

Darwis, S. D. 2013. Metode Penelitian Kebidanan Prosedur Kebijakan \& Etik. Jakarta: EGC

Djamarah, S. 2014. Psikologi Belajar. Jakarta: PT. Rineka Cipta.

Gibney, MJ., Margetts, BM., Kearney, JM., Arab, L., 2013. Gizi Kesehatan Masyarakat. Jakarta: EGC

Goleman, D. 2013. Emotional Intelligence: Mengapa emotional intelligence lebih penting daripada Intelectual Quotient. Alih Bahasa: Hermaya. Jakarta: PT. Gramedia Pustaka Utama.

Hardinsyah, P. F. 2015. Analisis jenis, jumlah, dan mutu gizi konsumsi sarapan anak Indonesia. Jurnal Gizi Pangan. 8(1). 2015.

Hornby; Pamwcll E.C \& Siswoyo.2013. Kamus Inggris - Indonesia. Jakarta: Indira.

Krummel DA \& Kris-Etherton PM. 2016. Nutrition in women's health. New York: Aspen.

Kusmiyati, Y. 2016. Kadar Hemoglobin dan Kecerdasan Intelektual Anak. Jurnal Kesehatan Masyarakat Nasional Vol. 8, No. 3, Oktober 2016

Luo R, Kleiman-Weiner M, Yue A, Martorell R, Lee M, Rozelle S, Zhang L, Liu C, Shi Y, Sharbono B. 2013. Anemia in rural China's elementary schools: prevalence and correlates in Shaanxi province's poor counties. Ecol Food Nutr. 2010. 49

Mayer, J. D., Ciarrochi, J. \& Forgas, J. P. 2016. Emotional Intelligence in everyday life: A scientific inquiry. London: National Gallery.

Pratama, I.Y. 2017. Korelasi Antara Kadar Hemoglobin Dengan Tingkat Konsentrasi Pada Mahasiswa Laki-Laki Fakultas KedokteranUniversitas HKBP Nommensen Medan. Nommensen Journal of Medicine. November 2017, 3(2).

Proverawati, A. 2011. Gizi untuk Kebidanan. Yogyakarta: Nuha Medika.

Purnama, I.M. 2015. Pengaruh Kecerdasan Emosional Dan Minat Belajar Terhadap Prestasi Belajar Matematika di SMAN Jakarta Selatan. Jurnal Formatif 6(3). ISSN: 2088-351X

Ristrini. 2014. Anemia akibat kurang zat besi keadaan, masalah, dan program penanggulangannya. Jakarta: Medika.

Salovey P and Mayer J. 2014. Emotional Intellidence. Imagination, cognition, and personality. Jakarta: PT Gramedia Pustaka Utama

Shapiro, Lawrence E. 2012. Mengajarkan Emotional Intelligence pada Anak, terj. Alex Tri Kantjono. Jakarta: Gramedia Pustaka Utama.

Suryabrata, S. 2016. Psikologi Pendidikan. Jakarta : Rajawali Pers

Tarwoto, W. 2012. Kebutuhan Dasar manusia dan Proses Keperawatan. Jakarta: Salemba Medika

Thohir, K., Nugraheni P., dan Jannah, M.H. 2014. Peningkatan Konsentrasi Belajar Menggunakan Metode Problem Solving. Jurnal: Program Studi Pendidikan Matematika Universitas Muhammadiyah Purworejo 
Tjundjing, S., 2011. Hubungan Antara IQ, EQ \& AQ dengan Prestasi Studi Pada Siswa SMU. Anima Indonesian Psychological Journal, Vol.17 no.1

Uno, H. 2014. Orientasi Baru dalam Psikologi Pembelajaran. Cetakan Ketiga. Jakarta: Bumi Antariksa

Veni , I. 2014. Pengaruh Anemia Terhadap Konsentrasi Belajar Anak Sekolah Dasar di Kabupaten Jombang. Jurnal Pendidikan Dasar, Vol.5, No.1

Yhamin, A. 2015. Pengaruh Kecerdasan Emosional Dan Minat Belajar Terhadap Penguasaan Konsep Matematika Siswa SMAN di Kecamatan Kebon Jeruk. Jurnal Formatif 5(1): 26-41, 2015. ISSN: 2088-351X 